\title{
Teacher Training System and Process: Opinions of Teacher Candidates on Teacher Qualifications
}

\author{
Arzu Aydogan Yenmez ${ }^{1}$, Ilknur Ozpinar ${ }^{1} \&$ Seher Mandaci Şahin ${ }^{1}$ \\ ${ }^{1}$ Department of Elementary Education, Nigde University, Nigde, Turkey \\ Correspondence: Arzu Aydogan Yenmez, Department of Elementary Education, Nigde University, Nigde, Turkey. \\ Tel: 90-388-225-4353. E-mail: aydogan.arzu@gmail.com
}

Received: April 4, 2016

doi:10.5539/hes.v6n3p114
Accepted: June 1, 2016

Online Published: July 28, 2016

URL: http://dx.doi.org/10.5539/hes.v6n3p114

\begin{abstract}
It is considered that teacher candidates offering their expectations and solution recommendations as well as assessing themselves on the competence aspect will be effective on eliminating the main problems in teacher training. In this respect, purposeof the research is to specify the opinions of teacher candidates on how they evaluate themselves and the faculty in which they study regarding qualifications they possess. The sample of the research conducted within the scope of descriptive study is consisted of 164 junior teacher candidates. The teacher candidates were askedfirst to examine the qualification documents as well as to identify the basic issues, and to answer a written interview form. The obtained data were examined under the themes of "deficiencies", "expectations" and "solution recommendations". Considering the outcome model, it is suggested that in-serviceprocess should be investigated in more details with new studies on subjects such as teacher recruitment and career development.
\end{abstract}

Keywords: teacher competence, teacher training, teacher candidates, teacher qualifications, practicum application school

\section{Introduction}

In line with developments in science and technology, changes to happen in education fieldas in all fields have been inevitablein our century. Education is perhaps the most importantbasic requirement needed for raising qualified individuals that can attunetothe developing and changing society.

In the society of our age, it is targeted to train individuals that are critical thinkers, can make decisions independently, and able to produce solution to the problems. The 21st century learners should constantly renew themselves in the form of adapting the changes in the education field by continuously adding new ones to their knowledge and what they have learned. "Lifelong learning" concept that emerged due to these needs imposes certain responsibilities to the educational institutions and learners (Köğce, Özpınar, MandacıŞahin, \& AydoğanYenmez, 2014). Because the function of the schools has changed in accordance with new approaches in education in which the extent of the learning concept has changed along with the acceptance of the concepts such as learning, active learning and lifelong learning. In parallel with this change, the schools that were previously accepted as basic resource for learning are no longer perceived as the single source; moreover, with the importance given to lifelong learning, the schools are expected to be institutions that need to be integrated with the society. The change of the qualifications that desired to be gained by the students is also one of the important reasons for the change in the school's function. In line with these qualifications, in addition to teaching-learning process, the tasks and responsibilities of the teachers have changed (Day, 2000; ETUCE, 2008; European Commission, 2012; Karacaoğlu, 2008).

Due to the fact that the role of teaching profession on country development has known by all societies today, countries had to review their systems again in higher education field in broad and in the teacher training institutions in narrow, had to assess, and had to re-structure these institutions in the light of developments required by the era (ETUCE, 2008; European Commission, 2011; Koster \& Dengerink, 2008). Therefore, in Turkey, like seen in all countries, National Qualifications Framework for Higher Education in Turkey (NQF-HETR) (Council of Higher Education [CoHE], 2009), Teacher Qualifications (Ministry of National Education [MoNE], 2011, 2006) and Narrow Field Qualifications (MoNE, 2008a) were determined by the 
related commissions by considering the competences that the graduates should have in broad and teachers in narrow.

\subsection{National Qualifications Framework for Higher Education in Turkey (NQF-HETR)}

European countries felt the need of structuring the higher education systems by re-evaluating them within the scope of common understanding, principles and approaches presented by the Lisbon (1997) and Bologna (1999) processes in which Turkey was included as well. Lisbon Process has begun with Recognition of Qualifications Concerning Higher Education of the Council of Europe/UNESCO Convention (Lisbon Recognition Convention), and aims to create a European Higher Education Systemassociatedwithraisingmanpower, supporting vocational training and lifelong learning which will meet the needs of the European knowledge society (CoHE, 2009). The Bologna Process is an unusual reform process that aims to create European Higher Education Area (EHEA) which is generated and maintained by the 47 member countries with the cooperation of many international organizations. It is not desired to turn the education systems of the EHEA member countries into one type higher education system; on the contrary, it is asked to establish a balance between diversity and unity. In other words, it is aimed to put the education systems within European geography in a position that is compatible with each other, easy to understand, and recognizable in national and international framework, and forming EHEA in accordance with the need of European Communities (CoHE, 2009, 2012). One of the important issues of these two processes is "European Qualifications Framework" which is developed with the same goal but with different approaches, and National Qualifications Frameworks (NQF) that is associated with these frameworks (CoHE, 2009). NQF is a system that includes definitions and approaches that are appropriate to countries' social, cultural and economic realities, accepted and applied by the higher education institutions of the countries, recognized by the stakeholders, and degrees may be given that are attributable (CoHE, 2010a).

The first studies launched to establish higher education national qualifications framework in Turkey were carried out by the Council of Higher Education after the MinisterialSummitheld within Bologna Process in Bergen in 2005 determining on the constitution of national qualifications framework. The members of the first Commission of Higher Education Qualifications was founded by the Council of Higher Educationin 2006, which were comprised of Council of Higher Education and Higher Education Institutions representatives, and continued their studies until February 4th, 2008. As a result of works executed between these dates by the Commission, NQF was generated by using mostly QF-EHEA (European Higher Education Area) level descriptors. After this, NQF-HETR's first draft study prepared according to competencies regarding knowledge, comprehending and implementing what is comprehended that are required to be gained minimally at the end of every degree (associate, bachelor, master and doctorate) of higher education was submitted to the views and contribution of the relevant stakeholders. Thereafter, commission members were renewed for the purpose of maintaining NQF works with a wider scale, and National Qualifications Commission and Working Groups were established with the participation of experienced academicians from different universities and disciplines to support the Commission's works. These groups have prepared the works they have done as "NQF-HETR Interim Report" in January 2009 and submitted it to the views of those concerned. As a result of feedback from the stakeholders, works have been carried out for the composition of NQF-HETR (CoHE, 2010b).

NQF-HETR License Identifiers (Learning Outcomes) containing education and training that are generated by considering that all competencies present in Turkish Education System and the competencies to be developed in time can be identified and associated within a wholeness, were discussed in three categories; knowledge (theoretical, practical), skills (conceptual/cognitive, practical) and personal and professional competence (the competence to work independently and to take responsibility, learning competence, communication and social competence, domain-specific and professional competence) (CoHE, 2009).

\subsection{Teaching Profession Broad and Narrow Field Qualifications}

One of the most important elements of the education system is the teachers. Thus, it is obvious that teachers play a strategic role in achieving education-training objectives (Çakmak \& Civelek, 2013). Accordingly, teacher training becomes the most important part of the education system (ETUCE, 2008).

Reasons such as the increase of learning opportunities for students by differentiation, presence of possibility that learning outside the target may occur, changes in the needs of subject fields, society and individuals, have been increasing the knowledge, skill and qualifications that teachers must have besides their duties and responsibilities by changing (Karacaoğlu, 2008). In other words, the qualification and quality of education is directly proportional to the qualification of the teachers. Enhancing the qualificationsof the teachers is possible first with having knowledge the competences required to be possessed by the teacher, and then, redounding these mentioned competences to the teachers and teacher candidates (Ar1, 2010; MoNE, 2006). 
Competence, in general, is an integrative concept concerning what a person can do (Carr, 1993) which is usually approached as a strong combination of knowledge, comprehension and skill in the literature (González \& Wagenaar, 2005; Koster \& Dengerink, 2008; ETUCE, 2008). These key concepts are also true for the teaching profession. For example; according to ETUCE (2008) teaching competence is the ability to provide knowledge integration, to overcome the difficulties and to respond the individual needs of students and groups. Ministry of Education (2010), on the other hand, defines teacher qualifications as "the integrity of knowledge, skill, attitude and values" by emphasizing on the "performance expected to be shown in order to fulfill a specific task or role".

Due to the fact that the level of teacher qualifications will affect the learning of student and the stability of learning (European Commission, 2012; Executive Summary, 2008; Karacaoğlu, 2008); competencies and characteristics teachers must possess have been continuously discussed in Turkey as well as all over the world (Ar1, 2010; ETUCE, 2008). Teacher education systemis varying in each country, and therefore the contents of qualification have been changing. In Turkey, Ministry of Education has identified teachers' competencies in twogroups. These are: Teaching Profession Broad Qualifications which include knowledge, skill and attitudes that all teacher must have, and Narrow Field Qualifications that containing knowledge, skill and attitudes regarding each teacher's own filed. The Teaching Profession Broad Qualifications consist of 6 competence areas (Personal and Vocational Values-Vocational Development, Student Recognition, Learning and Teaching Process, Monitoring and Evaluation of Learning and Development, School-Family and Community Relations, Program and Content Knowledge) (MoNE, 2006). In the Primary School Teaching Narrow Field Qualifications, on the other hand, Teaching-Learning Environment and Development, Monitoring and Evaluation, Personal and Vocational Development-Community Relations, Arts and Aesthetics, Development of Language Skills, Scientific and Technological Development, Individual Responsibility and Socialization, Physical Education and Safety topics are found (MoNE, 2008b).

Education and training having a dynamic structure in all aspects requires the teacher candidates who will play an important role in this process to be aware of their own competences, and constantly to question and improve their tasks and the qualifications necessary for these duties (MoNE, 2006). Therefore, teacher qualifications are discussed in many studies in the literature. Some studies have compared the undergraduate programs of related field with the competencies specific to the area (Arslan \& Özpınar, 2008; Çakmak \& Civelek, 2013; Kurudayığlu \& Tüzel, 2011), and in some studies the opinions of the teacher or teacher candidates was examined in order to evaluate area-specific narrow field qualifications (Kıldan et al., 2013; Kök, Çiftçi, \& Ayık, 2011; Coşkun, Metin, Birşiçi, \& KaleliYılmaz, 2010; Karacaoğlu, 2008; Avcı \& Cinoğlu, 2012; Akpınar, Turan, \& Tekataş, 2004; Özer \& Gelen, 2008). In terms of considering the literature, it is thought that teacher candidates who are characterized as teachers of future offering their expectations and solution recommendations, besides assessing themselves on the competence aspect, will be effective on eliminating the main problems in the teacher training system and process. In this respect, the main purpose of the research is to specify the opinions of teacher candidates on how they evaluate themselves and the faculty in which they study regarding qualifications they possess. In the direction of this purpose, answers to the following questions have been sought: i) Are teacher candidates find themselves competent, and what are the expectations? ii) Are teacher candidates find the faculty they study competent, and what are the expectations? iii) What kind of deficiencies they believe they have? iv) What are the solution recommendations?

\section{Method}

Qualitative research approach of case study was used in this study. As described by Creswell (2009), "case studies are a strategy of inquiry in which the researcher explores in depth a program, event, activity, process, or one or more individuals" (p. 13). The case needs not be a person "It can be whatever bounded system is of interest. An institution, a programme, a responsibility, a collection, a phenomenon or a population can be the case" (Gomm, Hammersley, \& Foster, 2000, p. 23). The case in this study was the phenomenon. The sample of the research is consisted of 164 junior teacher candidates who study in the Primary School Teaching Program, Faculty of Education, Turkey.

\subsection{Data Collection Tool and Analysis of Data}

The study was conducted in three branches within the scope of students who are studying in the Primary Education Teaching Program and Mathematics Teaching II course. The teacher candidates were asked first to examine the National Qualifications Framework for Higher Education in Turkey and the reports concerning Teaching Profession Broad and Narrow Field Qualifications, then to assess themselves and the faculties in which they studied in terms of competences and sub-competences stated in these documents as well as to identify the basic issues, and to answer a written interview form consisted of four questions which prepared for the purpose 
of presenting expectations and solution recommendations. The questions that were asked to the teacher candidates are as follows:

In the light of three reports that you have examined;

1) Write the competency level you find yourself in with the reasons, explain your expectations, if any.

2) Do you find the faculty in which you are studying adequate? What are your expectations?

3) According to you, what kind of deficiencies exist, and from which aspects (CoHE, university, faculty, academician, teacher candidate)?

4) What are your solution recommendations?

The teacher candidates participated to the interview were referred as TC1 (Teacher Candidate 1), TC2, ..., TC164. The answers of teacher candidates were coded by the researchers who conducted the study by considering the similarities and differences, and were classified based on responsible-related units and individuals. Afterwards, the classifications and codes generated by the researchers were examined together, the similar ones were clarified, the discussions were made on the dissimilar ones, and by reaching a consensus, the common codes and themes were established (Merriam, 1988; Yin, 1994).

\section{Results}

The opinions of teacher candidates on how they evaluate themselves and the faculty where they study regarding the competences they have were specified under themes of "deficiencies", "expectations" and "solution recommendations". Because of the fact that the same codes were situated under different themes as well, they were presented under the most emphasized theme. The percentage and frequency values of the codes determined concerning the responsible-related unit and individuals under the "deficiencies" theme are shown at Table 1.

Table 1. Distribution of the values determined upon "deficiencies" regarding teacher competences that teacher candidates have specified in themselves and the faculty where they study

\begin{tabular}{|c|c|c|}
\hline Codes & $\begin{array}{l}\text { (Frequency) } \\
\text { f }\end{array}$ & $\begin{array}{l}\text { (Percentage) } \\
\% *\end{array}$ \\
\hline \multicolumn{3}{|l|}{ For Academicians } \\
\hline Professional incompetence & 126 & 77 \\
\hline Applied courses are predominantly taught theoretically & 107 & 65 \\
\hline Lack of self-assessment & 21 & 13 \\
\hline Lack of assessment and evaluation & 26 & 16 \\
\hline Lack of technological knowledge and its usage & 14 & 9 \\
\hline Classes are taught without associating the subjects with social and daily livings & 23 & 14 \\
\hline Lack of informing on Curriculum & 18 & 11 \\
\hline \multicolumn{3}{|l|}{ For Students } \\
\hline Not setting academic goals, being confined with only passing the course & 11 & 7 \\
\hline Uncaring about the areas of the course usage and not liking the course & 16 & 10 \\
\hline Not using the technology & 72 & 44 \\
\hline Lack of knowledgein one's own field & 55 & 34 \\
\hline Lack of knowledge regarding interdisciplinary course contents & 9 & 5 \\
\hline Lack of effort for personal development (reading, etc.) & 61 & 37 \\
\hline Lack of effort for professional development (article monitoring, seminars, etc.) & 57 & 35 \\
\hline \multicolumn{3}{|l|}{ For Faculty } \\
\hline $\begin{array}{l}\text { Lack of physical conditions for activities regarding learning through doing and } \\
\text { experiencing }\end{array}$ & 36 & 22 \\
\hline Courses are insufficient that aim to enhance knowledge and technology literacy & 68 & 41 \\
\hline The execution of applications that support school-family-community relations are & 10 & 6 \\
\hline
\end{tabular}




\section{insufficient}

\section{For University}

Absence of social and cultural activities (personal development seminars, theater, cinema,

nature trips, etc.)

Absence of Practicum Application School

\section{For CoHE}

Central placement errors

Inadequacy of the admission criteria to the Faculties of Education

Imbalance in the distribution of theoretical and applied courses by years

Insufficiency of the applied courses and hours
62

*: The percent value may exceed $100 \%$, due to the fact that the answers of some teacher candidates were placed under more than one code.

Table 1 shows that most of the teacher candidates have emphasized on the professional incompetency of the academicians. In terms of professional incompetency, they indicated that many of the teaching staff do not have pedagogical formation as well as unaware of the learning standards of our era. They stated that they have stressed on these incompetences, because these incompetences negatively impact the learning process. The views of teacher candidates on this subject are listed below.

"[...] Some of the instructors that teach our classes do not even have pedagogical formation, so of course, this situation effects our studies. We can easily see the difference when we compare them with our other instructors." (TC 83)

"[...] Our instructors from education faculties manifest themselves with their attitudes and behaviors compared to our other instructors." (TC 25)

"Many of our instructors talk about training teachers that are appropriate to our age, however they remain incapable to train us in accordance with the needs of recent time." (TC 7)

The instructors predominantly teaching the applied courses theoretically has been interpreted by many teacher candidates as a deficiency. The teacher candidates indicate that information is mostly given by the teaching staffs with lecturing method; moreover, although the importance of constructivism and conceptual learning have been noted, this kind of learning is not provided to them; particularly, because of the fact that they are not receiving a conceptual-based education, they state that schools will experience some difficulties in terms of application and evaluation of this. The teacher candidates have explained this situation as follows:

"We are asked to provide training in schools based on the constructivist approach. However, our teachers do not train us in this way." (TC 12)

“... We do not receive student-centered education, so how we can provide education of this kind...” (TC 33)

"Lack of assessment and evaluation" code specified at above table is explained by the teacher candidates as that the teaching staffs do not provide sufficient theory and practice about the assessment, they do not use the alternative assessment-evaluation techniques, and they do not properly do the monitoring and evaluation of learning and development. In addition, the opinions of teacher candidates on the insufficiency of the courses regarding the increase of knowledge and technology literacy which was stated as a deficiency for the faculty.

"Within the context of Fatih Project, Ministry of Education, schools have been equipped with technology; however, we do not know how we should do training using this technology, courses are missing on this subject." (TC 114)

"I and my colleagues feel very incompetent in making teaching with technology. Let's say, the extra lessons have not been added in this regard, but at least they should teach us with the seminars." (TC 92)

"Central placement errors" specified under for CoHE in the tableis explained by the teacher candidates as that there are teacher candidates who are unqualified, inadequate, reluctant, careless and closed-minded to new ideas which are originated from the choice of the teaching profession not to be jobless. The main reason for this situation is shown to be the insufficiency of the entry criteria to the Faculties of Education. Based upon the different criteria, suggestions of teacher candidates are stated below. 
"I believe the personal development of those who prefer the teaching profession must be taken into consideration." (TC 46)

"[...] Also, their psychological status should be looked at. If they are not psychologically intact, how can they approach to the students with patience?" (TC 51)

Another deficiency identified for CoHEis given under the "imbalance in the distribution of theoretical and applied courses by years" code. Overall this imbalance was explained as the decrease on the performance as a result of the surplus number of theoretical courses in the first two years, and in the last two years the classes are more intense along with the applied courses; in fact, the concern of the Public Service Staff Selection Examination (KPSS). The teacher candidates have explained this situation as follows:

"The school experience and teaching practice courses are increasing in the last year, at the same time we continue to take courses during this period. In addition, we study for the PPSE, in which one can we be efficient?" (TC 148)

The percentage and frequency values of the codes determined on the "expectations" regarding competences of teacher candidates are shown at Table 2 .

Table 2. Distribution of the codes determined upon "expectations" regarding teacher competences that teacher candidates have specified

\begin{tabular}{|c|c|c|}
\hline Codes & $\begin{array}{l}\text { (Frequency) } \\
\mathrm{f}\end{array}$ & $\begin{array}{l}\text { (Percentage) } \\
\% *\end{array}$ \\
\hline \multicolumn{3}{|l|}{ For Academicians } \\
\hline The teaching staffs continue to guide the candidates after they start working & 64 & 39 \\
\hline \multicolumn{3}{|l|}{ For Students } \\
\hline Solving the problems concerning the application through experiencing & 28 & 17 \\
\hline \multicolumn{3}{|l|}{ For Faculty } \\
\hline Communicating more with schools adhere to the Ministry of Education & 35 & 22 \\
\hline Increasing the number of elective courses present in the academic program & 76 & 46 \\
\hline Eliminating physical inadequacy in the classes of the faculty & 44 & 27 \\
\hline \multicolumn{3}{|l|}{ For CoHE } \\
\hline Increasing applied courses and their hours & 151 & 92 \\
\hline Changing the entry criteria to the Faculty of Education & 103 & 63 \\
\hline Preventing the non-area placements & 7 & 4 \\
\hline
\end{tabular}

*: The percent values may exceed $100 \%$ due to the fact that the answers of so me teacher candidates were placed under more than one code.

Table 2 shows that many of the teacher candidates have emphasized on the stableness of the programs in the faculty. At this point, they gave suggestions on increasing the number of the courses such as regarding special field, technological field knowledge, and application, or reorganizing their contents. Some examples of teacher candidates' expressions are stated below.

"[...] When we look around, always the same courses are taught in different faculties, ok, they can be taught, but the faculties should be able to use their initiative regarding the request of students. For example, I want more lessons on how to use technology in my education and many of my classmates want the same thing as well. In that case, faculty should change the program content accordingly." (TC 5)

"[...] It is called elective course and I think it turns into a mandatory elective course. I want more applied-specific courses; however, I cannot find what I want in elective courses. When I speak with my friends from other universities, all talk about the same issue. Faculties should listen to their students and should able to take stepsindependently in accordance ..." (TC 132)

Under the codes of "more communication with schools adhere to the Ministry of Education" and "solving the problems concerning the applicationthrough experiencing", the teacher candidates stated that the faculties should 
be in communication with schools affiliated to the Ministry of Education more often, because when they go to the schools for their home works, the teachers and administrators see them as a burden; as a consequence, along with healthier communication, they can overcome this problem so that the Teaching Practice and School Experience class which they will enroll in the senior year may proceed more sufficiently. Moreover, they noted that with the positive experiences obtained in the schools, they could overcome the problems that may be encountered during the practice.

“[...] For example, with the aim of getting help from the teachers for the teaching lessons that we will lecture on, we go to schools. However, they do not help us much, they are disturbed by our presence. Seems like they are trying to pass us off. If this wasn't the case, we could go to them more often and ask for information." (TC 85)

"Now, our teachers also say that what we do in the faculty whether lecturing or practices are all artificial, meaning, we do our studies in the laboratory environment. In fact, we still experience difficulties. However, I am aware of that the real difficulty is the real school environment; my brother is also a teacher so that I know this from him. [...] On the other hand, there are Teaching Practice and School Experience classes in the senior year that we will take. Then, I think that we will gain more experience and we will find the opportunity to see everything in place." (TC 72)

One of the expectations that teacher candidates have stressed on among the elective classes was the "diction" class which was considered to be very important, eventually this class should be mandatory. In addition, the teacher candidates also mentioned on the physical inadequacies of the classrooms in the faculty, and stated their thoughts about this as follows:

"It's been one year since we have moved to this building, so it is newly built building. But I believe the classrooms are not appropriate to take classes. Begin with, the classrooms have echo problem. While our instructor is lecturing, even a low whispering makes an echo which disturbs the flow of the course. In my opinion, this problem should be solved. Moreover, the number of lecture hall is very few; in these lecture halls we can have lectures more comfortably because of both the seating arrangement and larger classrooms." (TC 123)

“[...] In my opinion, the number of microscope in science labs is not sufficient, I think we need to increase the number." (TC 18)

After teacher candidates evaluate the competencies they have based on their deficiencies and expectations, they offered "solution recommendations" in order to be a bachelor degree graduate that has teacher competencies. The percentage and frequency values of the codes determined under the "Solution Recommendations" themeare shown at Table 3.

Table 3. Distribution of the codes determined upon "solution recommendations" of the teacher candidates submitted in order to be a bachelor degree graduate that has teacher competencies

\begin{tabular}{|c|c|c|}
\hline Codes & $\begin{array}{l}\text { (Frequency) } \\
\text { f }\end{array}$ & $\begin{array}{l}\text { (Percentage) } \\
\% *\end{array}$ \\
\hline Personal development of teacher candidates must be supported & 83 & 51 \\
\hline The number of applied classes should be increased & 142 & 87 \\
\hline Course contents should be reconstituted & 63 & 38 \\
\hline The entry criteria to the Faculty of Education should be rearranged & 120 & 73 \\
\hline There must be an Practicum Application Schoolwithin the university & 113 & 69 \\
\hline School-Faculty cooperation should be ensured & 92 & 56 \\
\hline The teaching staffs should continue to guide the candidates after they start working & 88 & 54 \\
\hline Theoretical and practical courses should be evenly distributed according to year & 97 & 59 \\
\hline Courses regarding knowledge and technology literacy should be increased & 51 & 31 \\
\hline Training should be provided regarding teacher competencies & 128 & 78 \\
\hline Teaching staff who trains teachers should be trained as well on teacher competencies & 75 & 46 \\
\hline Cooperation with the graduates should be provided (benefiting from the experiences) & 32 & 20 \\
\hline
\end{tabular}


Table 3 shows that the teacher candidates have emphasized on the personal development. At the point of structuring this, they suggested to increase the number of seminars regarding personal and professional development in which magazine subscriptions can be obtained and reading habits can be imposed. Besides, they stressed on the importance of ensuring the cooperation with the graduates. They indicated that in this way, they could find the opportunity to benefit from the experiences of the graduates.

They also argued on the necessity of giving guidance service; because, teachers should be raised psychologically healthy, and they should learn how to treat students in unexpected situations.

When examining Table 3, it is seen that teacher candidates have focused on the necessity of the presence of pre-service and in-service courses and seminars regarding teacher competencies. They also suggested that the teaching staff who trains teachers should be trained as well on teacher competencies. Some statements of teacher candidates are stated below.

"[...] Now, just by reading, yes, we learned something about competencies. But if we were not asked to do a research, we would not have the knowledge of this; as a consequence, we must take a class only in regard to this subject. In fact, in my opinion, not only us but also our teachers should be informed." (TC 101)

In the solution recommendations, the teacher candidates have stated that Practicum Application School is necessary within the university, which will give an opportunity of constant communication between the guidance counselor in school and faculty member, and a productive learning environment will occur due to the fact that the guidance counselors will also be knowledgeable persons in their fields so that they will constitute a good example. They expressed their opinions on the necessity of Practicum Application School as follows.

“[...] For example, if we had a school within our university, our instructor could meet with the teacher in the school at any time; we would feel comfortable when we went to the school, and would ask the questions we want Because of the fact that our instructor will also give training to the teachers at one point, they will lecture based on constructivism in all likelihood. We can make very effective observations as well." (TC 85)

Finally, ensuring school-faculty partnership was offered by the teacher candidates as a solution recommendation. In particular, teacher candidates indicated that the teaching staff should constantly guide them in the schools, because the candidates cannot relate the concepts learned in the faculty with the practices applied in the schools. Teacher candidates also added that not to grow negative attitudes against the profession by being influenced from the practice teachers who are not aware of their tasks, practice teachers can continuously improve themselves on teaching profession through faculties organizing seminars in schools or notifying schools about the activities in the faculties. Teacher candidates have explained this situation as followed:

"Our teacher at the university wants us to lecture according to constructivism. However, neither teacher in the school nor the students are ready for this. They are used to the classical system. Always the teacher lectures, so that our instructors should be a supporter and guide to us when we go to schools [...]" (TC 67)

"When we go to schools, we see that some teachers do not really perform their profession by loving it, I think their jobs become like a torture to them. When we talk to our friends in the upper classes, some says that we live in some fantasy world. As such, we feel like becoming cold against the school. In my opinion, maybe seminars can be organized for the teachers or activities that are made can be delivered to them. Friends from the last year have mentioned that they have prepared projects on the subject of 'Mathematics and Life'. Then, they have invited the teacher in their schools, I think it was good." (TC 160)

\section{Discussion, Conclusion and Suggestions}

The opinions of the teacher candidates on how they evaluate themselves and the faculty where they study regarding qualifications they possess were examined under "deficiencies", "expectations" and "solution recommendation" themes. Professional deficiencies specified by the teacher candidates against the academicians under deficiencies theme were discussed in other sources as well (Kavcar, 2002; Köğce, Özpınar, MandacıŞahin, \& Aydoğan Yenmez, 2014). Kavcar (2002) has reported the issue on many of theinstructors of Faculty of Education not having pedagogical formation asthat "The Faculty of Education is seen as a place of employment by variety of faculty members who suffer from personnel issue". Another professional incompetence specified by the teacher candidates is that "the learning standards of our age are not known by the instructors"; therefore, in the other studies done with the instructors, this study being in parallel with the opinions of teacher candidates, 
it is concluded that the instructors do not have an extensive knowledge on the level that expected about the themes and sub-themes regarding 21st century Learning Standards (Köğce et al., 2014). One of other deficiencies specified by the teacher candidates against the academicians is thatthe information is mostly given by the instructors with lecturing method, and although the importance of constructivism and conceptual learning have been emphasized, this kind of learning is not provided to them. This view of teacher candidates also shows consistency with the determination specified in the study conducted by Noss and Baki (1996) in which that say "instructors should believe the conceptual knowledge as well and should give training in this aspect, and this view should be gained by the teacher candidates in the faculties".

Among the deficiencies of their own specified by the teacher candidates under deficiencies theme; not caring about the usage areas of the course, not liking the course, and aspects of inability to use technology were specified also among the 7 main mathematics teaching profession standard presented in the commission created by the American Mathematics Associations (Aydın, 1993). While "caring" which is one of the teaching profession standards is given as that the teacher candidates have understood the place and the importance of the mathematics in daily life; the "liking" standard was explained as really liking, appreciating the mathematics historically and culturally, and finding mathematics beautiful (Aydın, 1993). The other standard, "technology", was indicated as that "when teacher candidates are teaching or learning, they should use technology easily" (Aydin, 1993). It is reported that the priority goal is to reconstitute the contents of mathematics teaching programs in a way which will require to use more technology as well as the importance of the standard was stressed on (Aydın, 1993).

When the deficiencies, which are "imbalance in the distribution of theoretical and applied courses by years", "insufficiency of the applied courses and hours"; and expectations and solution recommendations which are "increasing applied courses and their hours, reconstituting the course contents, evenly distribution of the theoretical and practical courses according to year, increasing the number of courses regarding knowledge and technology literacy, increasing the number of elective courses present in the academic program" presented to the Council of Higher Education (CoHE) by the teacher candidates were discussed within the aspect of courses and their contents, the prominent case is the program flexibility. This situation has been reported in the study of Kavcar (2002) that the standard program approach is raising a staff for particular work, so it can be perceived as positive, because it must be raised along with the similar programs; "however, instead all classes are determined by CoHE, $20-30 \%$ of flexibility can be given to the faculties".

Teacher candidates have specified that the school experience and teaching practice courses are intensified in the last year, at the same time they continue to take classes in the university, and due to the fact that they prepare themselves to the Public Personnel Selection Examination (PPSE), the teaching practice classes are not productive. In their studies, Erbilgin and Boz (2013) have presented the similar factors that reduce the efficiency of teaching practice course. Teacher candidates' solution recommendation of "classes such as school experience and teaching practice should be evenly distributed to other years, besides the last year" is also found as a suggestion in the study of Eraslan (2009). Moreover, in their studies Erbilgin and Boz (2013) have introduced the view of that the school experience courses to be more effective, there should be a time period in which the teaching candidate should only do the internship without taking any classes a side.

In terms of looking at the statements that are present among the solution recommendations of teacher candidates "personal development of teacher candidates must be supported, training should be provided regarding teacher competencies, teaching staff who trains teachers should be trained as well on teacher competencies"; it is stated that pre-service and in-service classes and seminars regarding teaching competencies must be present. Safranhas emphasized that Faculty of Education programs were not designed by considering the teaching competencies, and the faculties are in static structure which is far from this dynamism are the significant problems (TEDMEM, 2014).

Teacher candidates indicated that classes regarding knowledge and technology literacy are insufficient, so that they submitted the expectations and solution recommendations such as the number of elective courses present in the academic program should be increased, and the support must be provided to teacher candidates in order to enhance the technology field knowledge. Overall, they stressed on that within the context of Fatih Project, Ministry of Education, schools have been equipped with technology; however, they are incompetent to give training, as a consequence they are inneed of the support (lectures, seminar, etc.) regarding enhancing the technology field knowledge.

Teacher candidates indicated that only the exams done at the entry of the profession are insufficient; moreover, some criteria must be considered at the admission to the Faculty of Education. This fact is present in the National 
Teachers' Strategy Document, in the action plans presented for the purpose improving the admission criteria to the programs that train teachers. The actions proposed for the entry criteria are explained as;

"To develop encouraging tools (increase of scholarships, housing guarantee at the dorms, etc.) so that successful students may prefer the teaching programs, including "Teaching profession knowledge" courses module in the general secondary education program as an elective, and taking the performances of the students who took this module into consideration at the admission to the Faculty of Education, in the medium term, in addition to the student acceptance to the teaching training programs and central placement exam, to develop the tools and criteria that will be constituted by the commission which will be established among the institutions for this purpose" (MoNE, 2011).

In the solution recommendations, teacher candidates have emphasized on the necessity of the Practicum Application School in the university, and school-faculty partnership. The necessity of the Practicum Application School in the university system was specified in other studies as "the instructor and practice teacher will have the opportunity to monitor the teacher candidates and evaluate their performances at the same time; in fact, because of the fact that the practice teachers will be experienced in their field and knowledgeable about the teacher raining, teacher candidates will have chance to gain experience within the productive and effective education and training environment" (Brooks, 2006; Eraslan, 2008; Penney \& Houlihan, 2003). In the solution recommendations specified regarding school-faculty partnership, teacher candidates especially indicated that the teaching staff should constantly guide the candidates in the schools, because the candidates cannot relate the concepts learned in the faculty with the practices applied in the schools. Imig and Switzer (1996) have concluded in their study that in order to raise successful teacher candidates, the teacher candidate, the practice teacher and the relevant instructor should work together, in coordination. Teacher candidates also suggested that not to grow negative attitudes against the profession by being influenced from the practice teachers who are not aware of their tasks, practice teachers can continuously improve themselves on teaching profession through faculties organizing seminars in schools or notifying schools about the activities in the faculties. The actions present in the National Teachers' Strategy Document, at the point of improving the teaching practice included in the pre-service teacher training program based on teaching qualifications were indicated as "to give mentorship training and certification to the successful managers and teachers who guide teaching practice in the schools in which the standards were defined by the Ministry of Education, to restructure the faculty-school partnership processes by considering mentorship practice, to make arrangements to ensure that the teacher candidates perform an actual practice with their mentors as full-time and in the branch in which they practice" (MoNE, 2011).

Training system and process of the qualified teachers specified with their teacher competencies can be modeled as follows within the light of the discussion mentioned above.

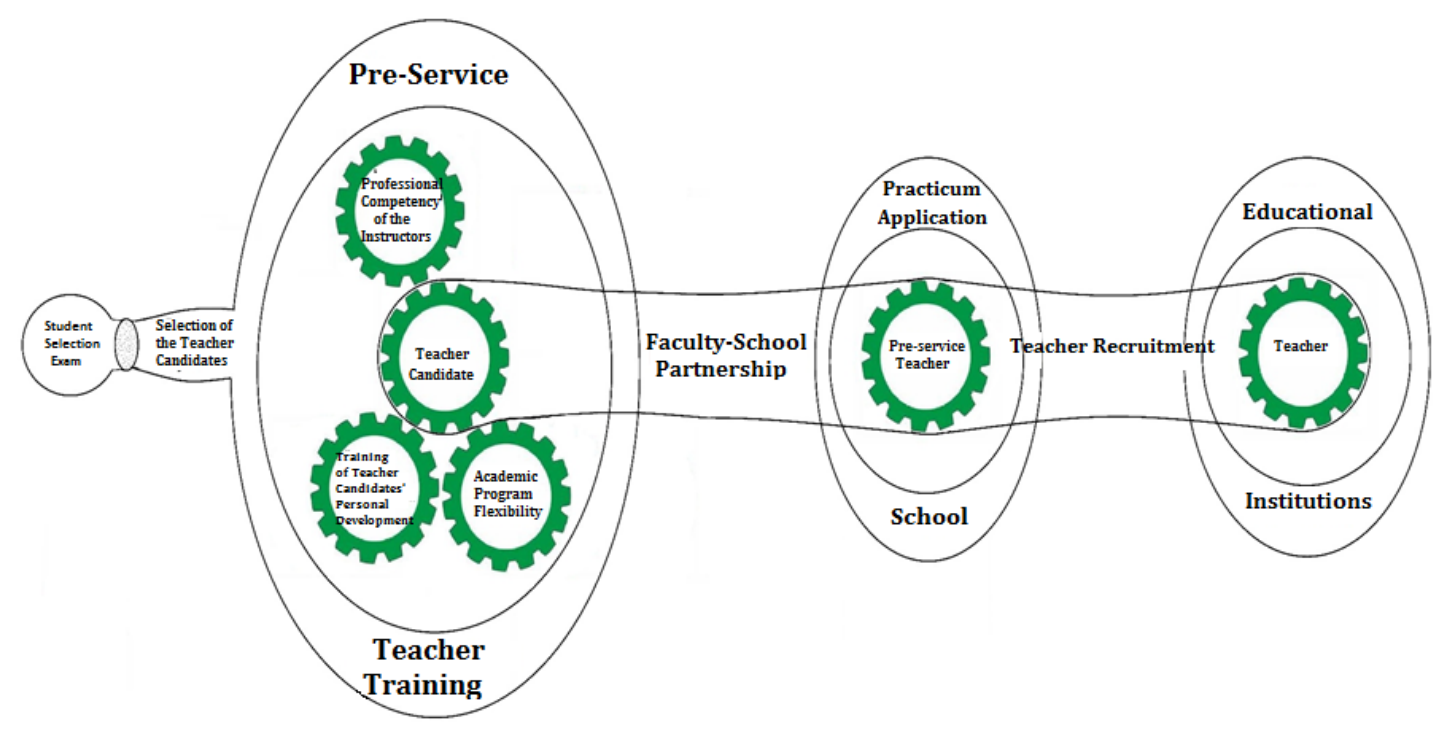

Figure 1. Teacher training system and process 
When the opinions of the teacher candidates on how they evaluate themselves and the faculty where they study regarding qualifications they possess were examined under "deficiencies", "expectations" and "solution recommendation" themes, the above system and process are found. Due to the fact that personal characteristics of the candidates directly influence their performances in the teaching profession, in addition to the student selection exam, which include only multiple-choice questions, used in the entry to the Faculty of Education, the necessity of reviewing the successful candidates once more by considering some criteria emerges. In the pre-service teacher training, on the other hand, by creating awareness regarding teacher qualifications at the point of "professional competency of the instructor" which is one of the most important wheels that affect the developmental cycle of teacher candidates, improving the qualifications. It is observed in the "training of the teacher candidates regarding their personal development" that by liking and caring the usage areas of the classes, the practices that support knowledge and technology literacy become important. Based on teacher competencies, within the scope of "academic program flexibility", practice being predominant, enhancing the hours and contents of the theoretical and applied classes come to the forefront. Looking at the school-faculty partnership process, the necessity of Practicum Application School play an important role on raising successful managers and teachers that will guide the teaching practice, and to enable the teacher candidates to gain experience in the teacher qualifications basis, within effective education-training environment, and under instructor guidance.

Considering the outcome model, while the period until transferring to become a teacher is shaped based on the opinions of the teacher candidates; it is found that the in-service process needed to be handled with the opinions of the teachers. It is suggested that in-service process should be investigated in more details with new studies on subjects such as teacher recruitment and career development.

\section{References}

Akpınar, B., Turan, M., \& Tekataş, H. (2004). Öğretmen adaylarının gözüyle sinıf ögretmenlerinin yeterlikleri. XIII. Ulusal EğitimBilimleri Kurultayı, İnönü Üniversitesi Eğitim Fakültesi: Malatya.

Arı, A. (2010). Öğretmen adaylarının ilköğretim programıyla ilgili eğitim fakültelerinde kazandıkları bilgi ve beceri düzeylerine ilişkin görüşleri. Selçuk Üniversitesi Ahmet Keleşoğlu Eğitim Fakültesi Dergisi, 29, 251-274. Retrieved from http://www.ide.konya.edu.tr/egtfakdergi/Sayilar/sayi29/15_AsimAri_251-274.pdf adresinden erişildi

Arslan, S., \& Özpınar, İ. (2008). Öğretmen nitelikleri: İlköğretim programlarının beklentileri ve eğitim fakültelerinin kazandırdıkları. Necatibey Eğitim Fakültesi Elektronik Fen ve Matematik Eğitimi Dergisi (EFMED), 2(1), 38-63.

Avcı, Y. E., \& Cinoğlu, M. (2012). Sınıf öğretmenlerinin özel alan yeterliklerine ilişkin görüşleri (Kilis ili örneği). Uş̧ak Üniversitesi Sosyal Bilimler Dergisi, 5(3), 108-128. Retrieved from http://sosyaldergi.usak.edu.tr/Makaleler/696701263_201203makale8.pdf adresinden erişildi

Aydın, Y. (1993). Matematik öğretmenin nasıl yetiştirilmeli? Hacettepe Üniversitesi Eğitim Fakültesi Dergisi, 9 , 109-114. Retrieved from http://dergipark.ulakbim.gov.tr/hunefd/article/view/5000049160 adresinden erişildi

Brooks, V. (2006). A "quiet revolution"? The impact of Training Schools on initial teacher training partnerships. Journal of Education for Teaching, 32(4), 379-393. Retrieved from http://wrap.warwick.ac.uk/443/1/WRAP_Brooks_9270464_170209_AQuietRevolution_articleforJET.pdf

Carr, D. (1993). Questions of competence. British Journal of Educational Studies, 41, 253-271. Retrieved from http://www.jstor.org/stable/pdfplus/3122287.pdf?acceptTC=true\&jpdConfirm=true

CoHE. (2009). Türkiye Yükseköğretim Ulusal Yeterlikler Çerçevesi (TYUYÇ) [National Qualifications Framework for Higher Education in Turkey (NQF-HETR)]. Retrieved from https://bologna.yok.gov.tr/files/1fd58513c8ad79fe43ca1b7c1adc4a8b.pdf

CoHE. (2010a). Türkiye Yükseköğretim Yeterlilikler Çerçevesi (TYYÇ) [Qualifications Framework for Higher Education in Turkey (QF-HETR)]. Retrieved from http://tyyc.yok.gov.tr/?pid=11

CoHE. (2010b). Türkiye Yükseköğretim Yeterlilikler Çerçevesi (TYYÇ) Özet Raporu [Qualifications Framework for Higher Education in Turkey (QF-HETR) Summary Report]. Retrieved from https://bologna.yok.gov.tr/files/aba1db502f39f3f98c99be21 ebecb132.pdf

CoHE. (2012). The Council of Higher Education of Turkey. Bologna process of Turkey. Retrieved from $\mathrm{http} / / /$ bologna.yok.gov.tr/?page=yazi\&c $=1 \& \mathrm{i}=3$

Coşkun, K., Metin, M., Birşiçi S., \& Kaleli Yılmaz, G. (2010). Farklı mesleki deneyime sahip sınıf ögretmenlerinin mesleki yeterlik ile ilgili algllamalart. International Conference on New Trends in 
Education and Their Implications, Antalya. Retrieved from http://www.iconte.org/FileUpload/ks59689/File/78.pdf adresinden erişildi

Çakmak, E., \& Civelek, F. (2013). Sınıf öğretmenliği lisans programının MEB özel alan öğretmen yeterlikleri açısından incelenmesi. Elektronik Sosyal Bilimler Dergisi, 12(47), 349-367. Retrieved from http://dergipark.ulakbim.gov.tr/esosder/article/view/5000068650/5000063711adresinden erişildi

Day, C. (2000). Teachers in the Twenty-first Century: Time to renew the vision. Teachers and Teaching: Theory and Practice, 6(1), 101-115. Retrieved http://www.tandfonline.com/doi/abs/10.1080/135406000114771\#.VJAvLCuUde8

Eraslan, A. (2008). Fakülte-Okul İşbirliği Programı: Matematik öğretmeni adaylarının okul uygulama dersi üzerine görüssleri. Hacettepe Üniversitesi Eğitim Fakültesi Dergisi, 34, 95-105. Retrieved from http://dergipark.ulakbim.gov.tr/hunefd/article/.../500004578 adresinden erişildi

Eraslan, A. (2009). Finlandiya'nın PISA'daki başarısının nedenleri: Türkiye için alınacak dersler. Necatibey Eğitim Fakültesi Elektronik Fen ve Matematik Eğitimi Dergisi (EFMED), 3, 238-248.

Erbilgin, E., \& Boz, B. (2013). Matematik öğretmeni yetiştirme programlarımızın Finlandiya, Japonya ve Singapur programları ile karşılaştırması. Hacettepe Üniversitesi Eğitim Fakültesi Dergisi [Hacettepe University Journal of Education], Özelsayl(1), 156-170.

ETUCE (European Trade Union Committee for Education). (2008). Teacher education in Europe. In An ETUCE Policy Paper. Brussels: ETUCE.

European Commission. (2012). Supporting the teaching professions for better learning Outcomes. Strasbourg. Retrieved from http://ec.europa.eu/education/policy/school/doc/teachercomp_en.pdf

Executive Summary. (2008). Teaching in the 21st century, A review of the issues and changing models in the teaching profession. Washington DC, USA: Blackboard public company publishing.

González, J., \& Wagenaar, R. (Eds.). (2005). Tuning educational structures in Europe II: Universities' contribution to the Bologna Process. Bilbao and Groningen: University of Deusto \& University of Groningen. Retrieved from http://tuning.unideusto.org/tuningeu/

Imig, D. G., \& Switzer, T. J. (1996). Changing teacher education programs. In R. W. Houston (Ed.), Handbook of research on teacher education (pp. 213-226). New York: Macmillan.

Karacaoğlu, Ö. C. (2008). Öğretmenlerin yeterlik algıları. Yüzüncü Yıl Üniversitesi, Eğitim Fakültesi Dergisi, 5(1), 70-97.

Karakaya, İ. (2012). Bilimsel araştırma yöntemleri. In A. Tanrı̈ğğen (Ed.), Bilimsel araştırma yöntemleri içinde (pp. 57-83). Baskı, Ankara: AnıYayıncılık.

Kavcar, C. (2002) Cumhuriyet döneminde dal öğretmeni yetiştirme. Ankara Üniversitesi Eğitim Bilimleri Fakültesi Dergisi, 35, 1-2.

Kıldan, A. O., İbret, B. Ü., Pektaş, M., Aydınözü, D., İncikabı, L., \& Recepoğlu, E. (2013). Evaluating views of teacher trainees on teacher training process in Turkey. Australian Journal of Teacher Education, 38(2), 51-68. Retrieved from http://ro.ecu.edu.au/ajte/vol38/iss2/4/

Koster, B., \& Dengerink, J. J. (2008). Professional standards for teacher educators: How to deal with complexity, ownership and function. Experiences from the Netherlands. European Journal of Teacher Education, 31(2), 135-149. Retrieved from http://dspace.library.uu.nl/handle/1874/31852

Köğce, D., Özpınar, İ., Mandacı Şahin, S., \& AydoğanYenmez, A. (2014). Öğretim elemanlarının 21.yüzyıl öğrenen standartları ve yaşamboyu öğrenmeye ilişkin görüşleri. Dicle Üniversitesi Ziya Gökalp Ĕgitim Fakültesi Dergisi, 22, 185-213. 2 Retrieved from $\mathrm{http}: / /$ www.zgefdergi.com/DergiTamDetay.aspx?ID=421\&Detay=Ozet adresinden erişildi

Kök, M., Çiftçi, M., \& Ayık, A. (2011). Öğretmenlik mesleği özel alan yeterliklerine ilişkin bir inceleme (Okul öncesi öğretmenliği örneği). Atatürk Üniversitesi Sosyal Bilimler Enstitüsü Dergisi, 15(1), 169-183. Retrieved from http://e-dergi.atauni.edu.tr/ataunisosbil/article/view/1020007608 adresinden erişildi

Kurudayığlu, M., \& Tüzel, S. (2011). Türkçe eğitimi lisans programının Türkçe öğretmeni özel alan yeterlikleri açısından incelenmesi. Türkçe Eğitimi Bölümü Çalıştayı I, Sakarya Üniversitesi Eğitim Fakültesi: Sakarya.

MoNE. (2006). Öğretmenlik mesleği genel yeterlikleri [Teacher Qualifications]. Ankara: Ministry of National Education of the Republic of Turkey. Retrieved from http://otmg.meb.gov.tr/YetGenel.html 
MoNE. (2008a). Öğretmenlik mesleği özel alan yeterlikleri [Teacher Qualifications and Narrow Field Qualifications]. Ankara: Ministry of National Education of the Republic of Turkey. Retrieved from http://otmg.meb.gov.tr/belgeler/ogretmen_yeterlikleri_kitabi/Öğretmen_Yeterlikleri_Kitabı_özel_alan_yeter likleri_ilköğretim_açıklama_parça_3.pdf

MoNE. (2008b). Sinıf ögretmenliği özel alan yeterlikleri [Primary School Teaching Narrow Field Qualifications]. Ankara: Ministry of National Education of the Republic of Turkey. Retrieved from http://otmg.meb.gov.tr/alansinif.htmlurl-6

MoNE. (2011). Ulusal ögrretmen strateji belgesi [National Teachers' Strategy Document]. Retrieved from http://egitim.erzincan.edu.tr/userfiles/ulusalogr.doc

Merriam, S. B. (1988). Case study research in education: A qualitative approach. San Francisco, C.A: Jossey-Bass.

Miles, M. B., \& Huberman, A. M. (1994). Qualitative data analysis (2nd ed.). Thousand Oaks, CA: Sage.

Noss, R., \& Baki, A. (1996). Liberating school mathematics from procedural view. J. Educ. Hacettepe Univ., 12, 179-182.

Özer, B., \& Gelen, İ. (2008). Öğretmenlik mesleği genel yeterliklerine sahip olma düzeyleri hakkında öğretmen adayları ve öğretmenlerin görüşlerinin değerlendirilmesi. Mustafa Kemal Üniversitesi Sosyal Bilimler Enstitüsü Dergisi, 5(9), 39-55.

Penney, D., \& Houlihan, B. (2003). Higher education institutions and specialist schools: Potential partnerships. Journal of Education for Teaching, 29(3), 235-248. Retrieved from http://www.tandfonline.com/doi/abs/10.1080/0260747032000120123\#.VJA9NSuUde8

TEDMEM. (2014). Mustafa Safran ile ögrretmen istihdam politikalar üzerine bir söyleşi. Retrieved from http://www.tedmem.org/haberler/2014/02/07/profdr_mustafa_safran_ile_ogretmen_istihdam_politikalari_uz erine_bir_soylesi.html

Yin, R. K. (1994). Case study research design and methods (2nd ed.). Thousand Oaks, CA: Sage Publications.

\section{Copyrights}

Copyright for this article is retained by the author, with first publication rights granted to the journal.

This is an open-access article distributed under the terms and conditions of the Creative Commons Attribution license (http://creativecommons.org/licenses/by/4.0/). 